\title{
SAPMS; Student Assessment Process Management System Enriched with Quality Factors
}

\author{
Abdelghafar M. Elhady, A. E. Hassan \\ Lecturer, Institute of Scientific Research and Revival of Islamic Heritage, \\ Umm Al-QuraUnivearsity, KSA. \\ Abdelghafar.elhady@gmail.com \\ Dept. of Electrical Power,Faculty of Engineering \\ Mansoura University, Egypt \\ arwaahmed1@gmail.com
}

\section{ABSTRACT}

Computer's hardware and software development aided education field progresses more rapidly. Not only the computer is used in learning and assessment processes to add more attractiveness, but also it's used for better performance of educational system. But one of more defects was lacking in applying modern educational quality factors to both learning and assessment software. This paper presents a web based Student Assessment Process Management System (SAPMS). SAPMS provides a secured, attractive, easy to use and quality based assessment system. Our system is completely analyzed and designed using the Unified Modeling Language (UML). We also present the implementation of the core components of the SAPMS which performs the most important processes in the system. In addition to that a validation study for the system components is performed.

\section{Indexing terms/Keywords}

Process Management System, Software Application, Computer Aided Education, Student Assessment, Quality Standards.

\section{Academic Discipline And Sub-Disciplines}

Computer Science and Information System, Software Engineering.

\section{SUBJECT CLASSIFICATION}

Information System, Computer Aided Education Software Application.

\section{TYPE (METHOD/APPROACH)}

Authors depends on making scientific survey on the Student Assessment Software and educational Quality Standards.and the output system is validatied using real experimental approach to measure the system result.

\section{Council for Innovative Research}

Peer Review Research Publishing System

Journal: INTERNATIONAL JOURNAL OF COMPUTERS \& TECHNOLOGY

Vol 12, No.1

editor@cirworld.com

www.cirworld.com, member.cirworld.com 


\section{INTRODUCTION}

Education is one of the most important sectors that any country needs to develop. In educational sector, the learning experts should design learning programs that must be defined well by specifying the learning outcomes of this course and determining the methodology that will be used to make students earn knowledge and skills needed to satisfy these learning outcomes and prepare students to the next learning stages.

Assessment process has always been as an integral part of learning, and teaching. In recent years it has become a focus of attention for students, parents, practitioners, researchers, policy makers and the media.

In addition to teach students new skills and knowledge, assessment is so important to find ways to measure the knowledge and skills level of students continuously. Before conducting the program, determining whether student has the minimum level of skills and knowledge that enable them to interact with the learning program efficiently or not. During learning program, it helps in determining either student's skills and knowledge progress is satisfied or there is problem in learning process. After learning program, it's important to measure the overall achievement in learning program and suggest recommendations that help all partners in the learning environment.

We use the term assessment to summarize all activities that teachers use to help learners learn and to quantify the learning progress and outcomes [1]. The latter in particular means that assessment measures and documents the knowledge, skills and attitudes of an individual learner, a learning community (e. g., class, course, or workshop), or an educational institution.

However, the student assessment in education system is important, the current student assessment systems didn't provide sufficient security issues to protect Student Assessment's processes and data[2-10]. They also didn't provide the total quality perspectives in student assessment field. Finally, they didn't use management approach which enable Assessment System to be more agility like Business Process Management approach.

The contribution of this paper is two-fold. It presents a system that tries to answer the following question: How to build a secured web enabled process management system that manages all student assessment processes. And at the same time the system meets all quality perspective in student assessment field.

This paper is organized as follows. Section 2 reviews related work. Section 3 displays Then Proposed SAPMS Analysis and Design. After that, the SAPMS Implementation Results are shown in section 4. Finally, the system Validation is shown and illustrated.

\section{STUDENT ASSESSMENT RELATED WORK}

Xiao Ming et al in [2] proposed a Computer- Assisted Assessment and Diagnosis (CAAD) system for arts studentsoriented computer education. This system is used for special diagnostic teaching and self-test exercises and final examination. This system is limited as an assessment system, where it doesn't provide student tailored exams for training and self assessment purposes. It also doesn't added quality ILOs in the questions, and doesn't provide question feedback.

Alexandru Botu et al in [3] developed An interactive on-line e-Learning system with assessment component targeted at training public service administration employees and named it SIIPAL system. The assessment component in SIIPAL system didn't relate the test questions with ILOs and knowledge skills they support. Also the system didn't present the security issues used in the system which provide the system reliability and efficiency. It doesn't provide any feedback or recommendations to students or teachers.

Eugene Essa et al in [4] presented a tool, named ABET Course Assessment Tool (ACAT). It is a web-based application designed to assist in the collecting of data and generation of standardized assessment reports. This tool is very good as an assessment reporting tool but has a significant shortage. It depends on capturing the student scores manually and hasn't facility of integrating with other assessment systems which provide exams management system. But this tool prevents teachers from exporting student scores directly into ACAT.

Fahad T. Alotaiby et al in [5] proposed adaptive learning system with assessment that serves both students and teachers. The system consists of three parts teaching, learning and administration. The adaptive learning system proposed by Alotaiby concentrate on two types of persons in the education system; student and teacher; and don't take other parts in consideration like parents, market companies and research centers. The system lakes feedback feature on individual question, test and overall student progress levels.

Andrea Gorra et al [6] provide an account of the use of integrated assessment with a focus on the area of database teaching at Level 2 in the INN Faculty. Integrated assessments are also known as synoptic assessments. Even though group work and peer assessments are important elements of the curriculum, they could not be considered within the scope of this research. They also did not provide a complete view on the assessment and its persons' types.

Judit Jassó et al in [7] report and analyze the assessment component in blended e-learning system called e-studium project which is based on an op en-source platform like Moodle. This assessment component depends on the interaction between only student and teacher in the learning environment and ignore other actors. It also doesn't provide training environment for students to evaluate themselves. Although the system is auto grading, student can't see his test score till teacher deliver it to him after assessing process. 
2.1 Student Assessment Software (SAS) Comparison:

In this section we will compare between set of SAS currently exist in the market. Our comparison depends on set of references and web sites of these systems.

Table 1. Student Assessment Systems Comparison

\begin{tabular}{|c|c|c|c|c|c|c|}
\hline & Conegro[39] & $\begin{array}{l}\text { Onyx Test } \\
\text { Suite[40] }\end{array}$ & $\begin{array}{c}\text { ASDEL } \\
\text { project }[41,42]\end{array}$ & $\begin{array}{c}\text { Respondus } \\
\text { [43] }\end{array}$ & $\begin{array}{c}\text { Articulate } \\
\text { Quizmaker } \\
\text { [44] }\end{array}$ & TCExam [45] \\
\hline $\begin{array}{l}\text { Application } \\
\text { Type }\end{array}$ & $\begin{array}{c}\text { web-based } \\
\text { software for } \\
\text { Assessment } \\
\text { authoring and } \\
\text { delivery system }\end{array}$ & $\begin{array}{c}\text { web enabled } \\
\text { software consists of } \\
\text { set of independent } \\
\text { components used to } \\
\text { test and evaluate } \\
\text { students }\end{array}$ & $\begin{array}{c}\text { Assessment } \\
\text { Delivery Engine }\end{array}$ & $\begin{array}{c}\text { Exams } \\
\text { Authoring tool }\end{array}$ & $\begin{array}{l}\text { Flash-based } \\
\text { quizzes } \\
\text { authoring tool }\end{array}$ & \begin{tabular}{|} 
Web-based \\
software to \\
generate and \\
manage online \\
tests and exams
\end{tabular} \\
\hline $\begin{array}{l}\text { Multi language } \\
\text { Support }\end{array}$ & Yes & No & No & No & No & Yes \\
\hline $\begin{array}{l}\text { Security issue } \\
\text { used }\end{array}$ & Not presented & Not presented & Not presented & Not Presented & Not used & \begin{tabular}{|c|} 
Support 10 \\
access level with \\
IP
\end{tabular} \\
\hline Support ILOs & No & No & No & No & No & No \\
\hline $\begin{array}{l}\text { Question bank } \\
\text { management }\end{array}$ & $\begin{array}{c}\text { With } 15 \text { type of } \\
\text { questions }\end{array}$ & No & Yes & $\begin{array}{l}\text { Support } 15 \\
\text { type of } \\
\text { questions }\end{array}$ & \begin{tabular}{|c|} 
supports \\
different \\
graded and \\
survey \\
question types \\
\end{tabular} & \begin{tabular}{|} 
supports both \\
multiple-answer \\
questions and \\
free-answer \\
questions
\end{tabular} \\
\hline $\begin{array}{l}\text { Exam } \\
\text { management }\end{array}$ & Yes & Yes & Yes & Yes & Yes & Yes \\
\hline Exam types & Random exam & static exam & Random Exam & Random Exam & Static exam & Random Exam \\
\hline $\begin{array}{l}\text { Examination } \\
\text { platform }\end{array}$ & No & Yes & Yes & No & Yes & Yes \\
\hline $\begin{array}{l}\text { Feedback } \\
\text { methods }\end{array}$ & \begin{tabular}{|c|} 
On Question \\
level, and overall \\
semester level
\end{tabular} & $\begin{array}{l}\text { Individual test } \\
\text { feedback }\end{array}$ & $\begin{array}{l}\text { Exam level } \\
\text { feedback }\end{array}$ & No & $\begin{array}{c}\text { Question level } \\
\text { feedback }\end{array}$ & No \\
\hline $\begin{array}{l}\text { Assessment } \\
\text { reports }\end{array}$ & $\begin{array}{l}\text { set of reports } \\
\text { that analyze } \\
\text { students } \\
\text { performing }\end{array}$ & $\begin{array}{l}\text { Graphical analysis } \\
\text { of individual and } \\
\text { group result }\end{array}$ & Results reports & No & $\begin{array}{l}\text { Results and } \\
\text { actions reports }\end{array}$ & Results reports \\
\hline $\begin{array}{l}\text { Import\&Export } \\
\text { facility }\end{array}$ & Yes & Yes & Yes & $\begin{array}{l}\text { Export exams } \\
\text { only }\end{array}$ & $\begin{array}{l}\text { Export results } \\
\text { to email or } \\
\text { LMS }\end{array}$ & $\begin{array}{l}\text { Export exam to } \\
\text { pdf format and } \\
\text { results to email }\end{array}$ \\
\hline $\begin{array}{l}\text { Advertizing } \\
\text { facility }\end{array}$ & No & No & No & No & No & No \\
\hline
\end{tabular}

From comparison stated (see table 1), we found that all systems are not collaborative assessment systems. The most of these systems lack security issues equivalent with the important and sensitivity of system data. They also didn't support ILOs based assessment, all types of feedback (question level, exam level, time period level, individual and group level, and feedback methods between students and teachers for formative assessment). They don't help teacher in creating balanced exam which covers all important items in the course being tested. These systems also don't provide statistical and graphical reports for all types of users.

\section{THE PROPOSED SAPMS ANALYSIS AND DESIGN}

In this section, we will present high level abstraction of the SAPMS by representing all entities interact with the SAPMS as shown in figure 1. There are three types of entities which interact with the proposed system. First type is those systems in UIS which have roles in the SAPMS by providing data to the system or receiving data from the system. These systems as follow: 


\section{- Faculty Management System}

This system provides the needed data of college's faculty.

- Education and Student Management system.

This system provides student's data to SAPMS and receives student's grades.

- Graduates Studies and Research Management System.

This system provides data of post graduate studies' students to SAPMS and receives their grades.

- Learning Management System.

This system provides all data about modules, topics and ILO's needed for creating question bank and exams and receives data about the learning modules and techniques need to be improved.

\section{- Engineering Affairs Management System.}

This system provides data of all colleges' physical resources data including laboratories, ateliers, mechanical, and electronical equipments.

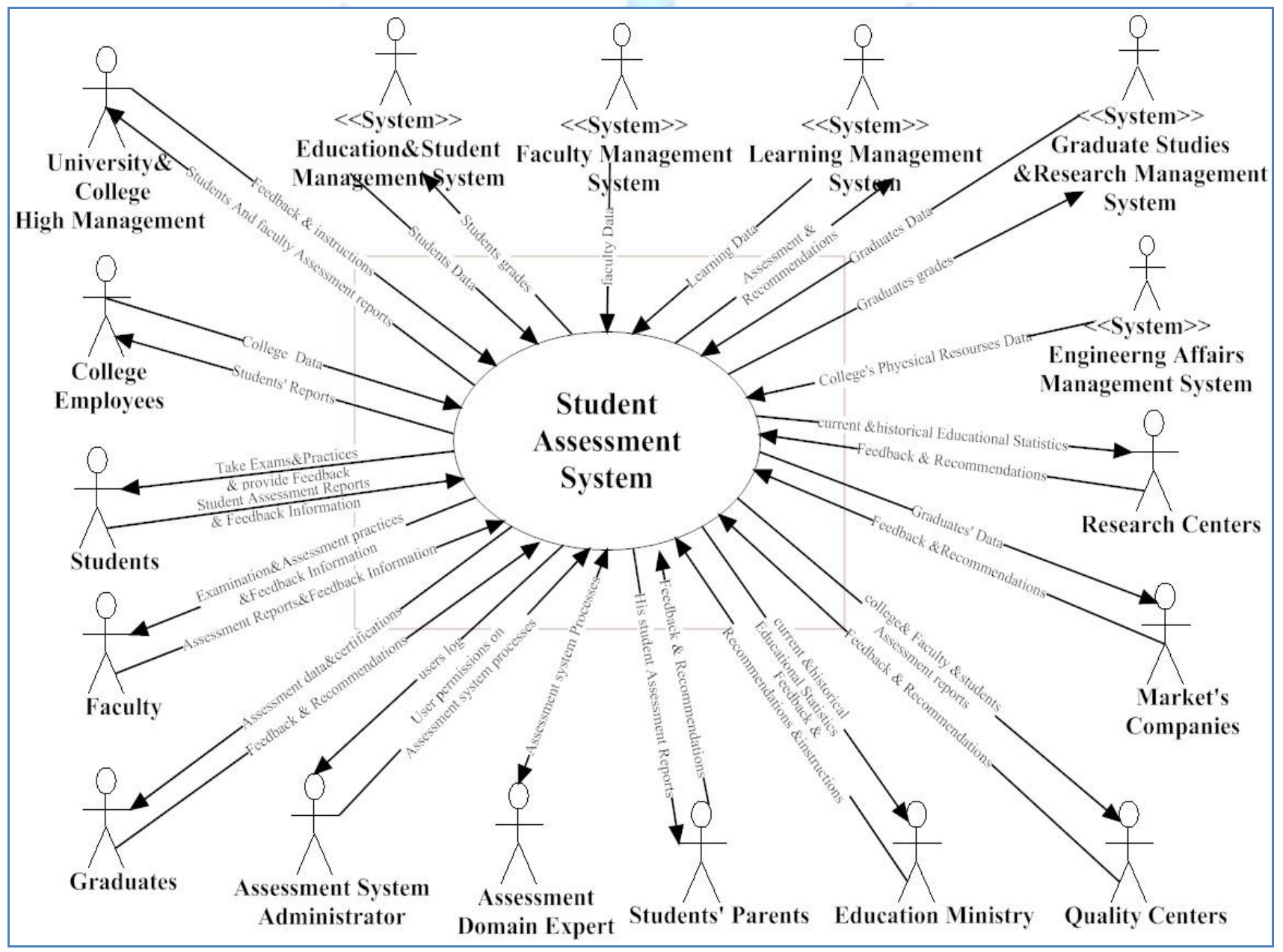

Fig 1: The Use Case Diagram of the SAPMS

The second type is human entities which is the target of the system such as student, faculty and graduates or receive reports from it such as college employee, student's parents, quality center, and university and college high management. The third type of entities is the external entities either governmental such as education ministry, market's companies, or research centers.

To achieve the previous point of view we design an extensive database. Figure 2 represents the general class diagram of the SAPMS database structure. 


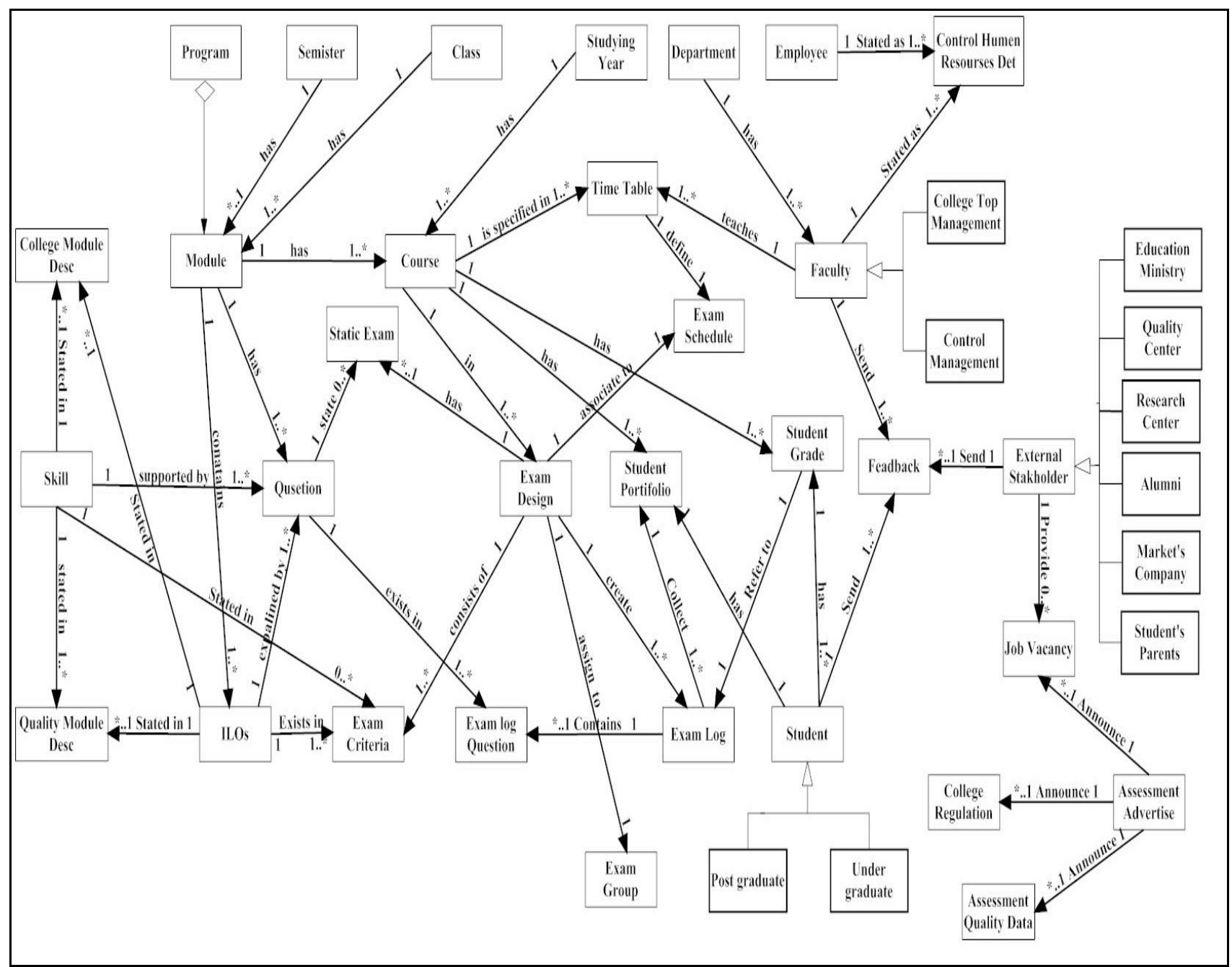

Fig 2: The Class Diagram of SAPMS

\section{SAPMS IMPLEMENTATION RESULT}

In this section we will display the output of the SAPMS Implementation by showing the important forms and reports of core components of the SAPMS.

\subsection{College Management Component}

Through this component, user can manage all college data needed to operate SAPMS such as regulations data, course data, faculty data, students' data, time table data....etc. Figure 3, and 4 show the forms which used to manage college data

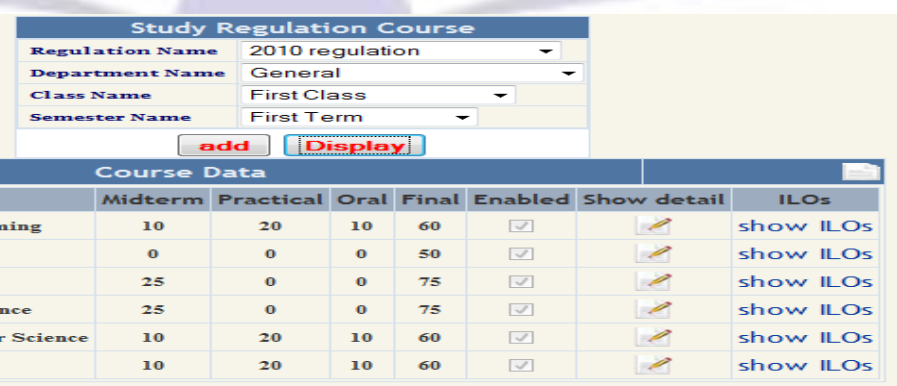

Fig 3: Study Regulation Courses Search Form 


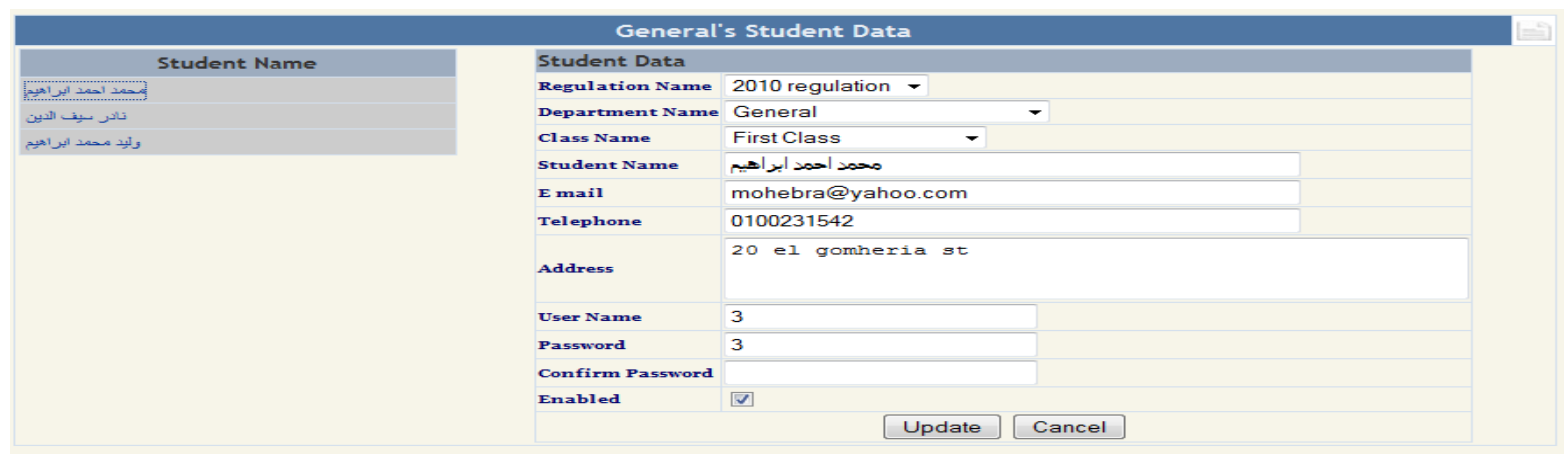

Fig 4: Manage Students' Data Form

\subsection{Quality\& Regulations Component}

This component automates the college regulations and quality related to assessment processes such as managing courses' topics, defining course Description matrix, defining exam quality matrix for each assessment type (Written, Oral, Practical and Home work)....etc. Figure 5,6, and 7 show the forms which used to manage Quality and Regulations' data.

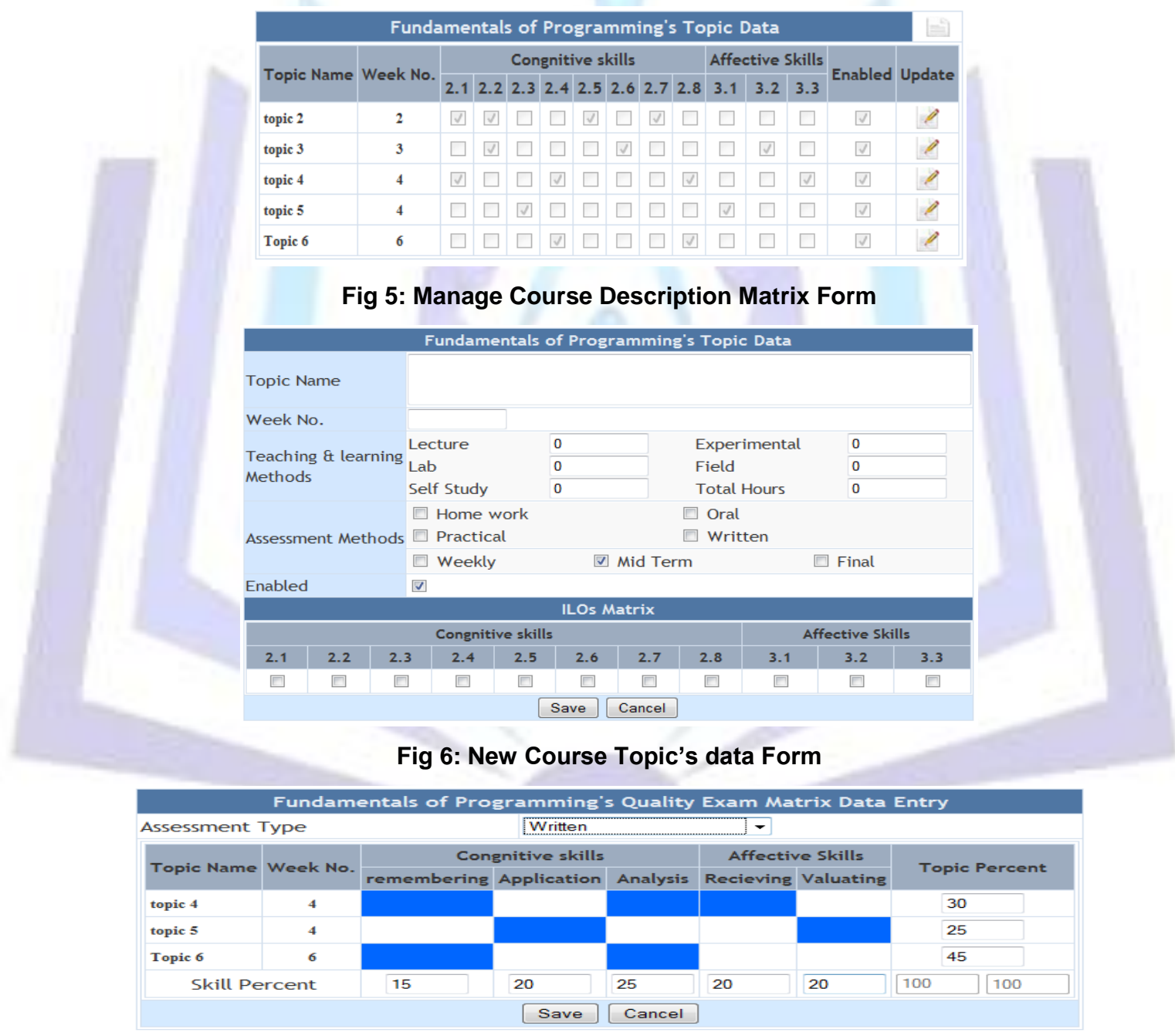

Fig 7: Exam Quality Matrix Form

\subsection{Questions Bank and Exam Generator Component.}

This component automates the question bank management and exam generating processes such as creating and managing modules' questions data and generating different types of exams like criteria based random exam and quality based random exam. Figures 8,9, AND 10 show the forms which used to manage question's data and generates different types of exams. 


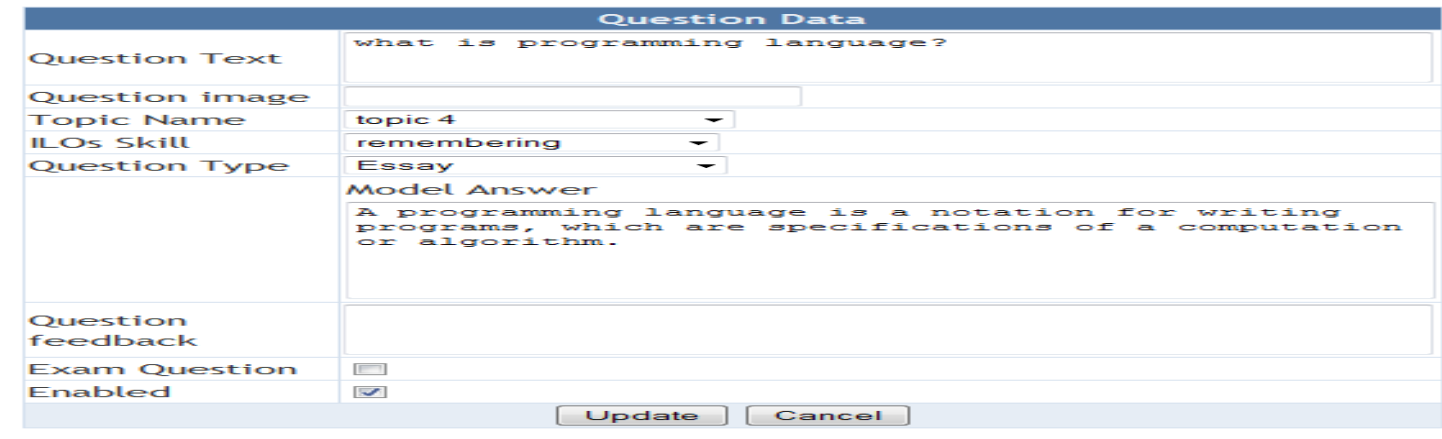

Fig 8: Manage Question Data Form

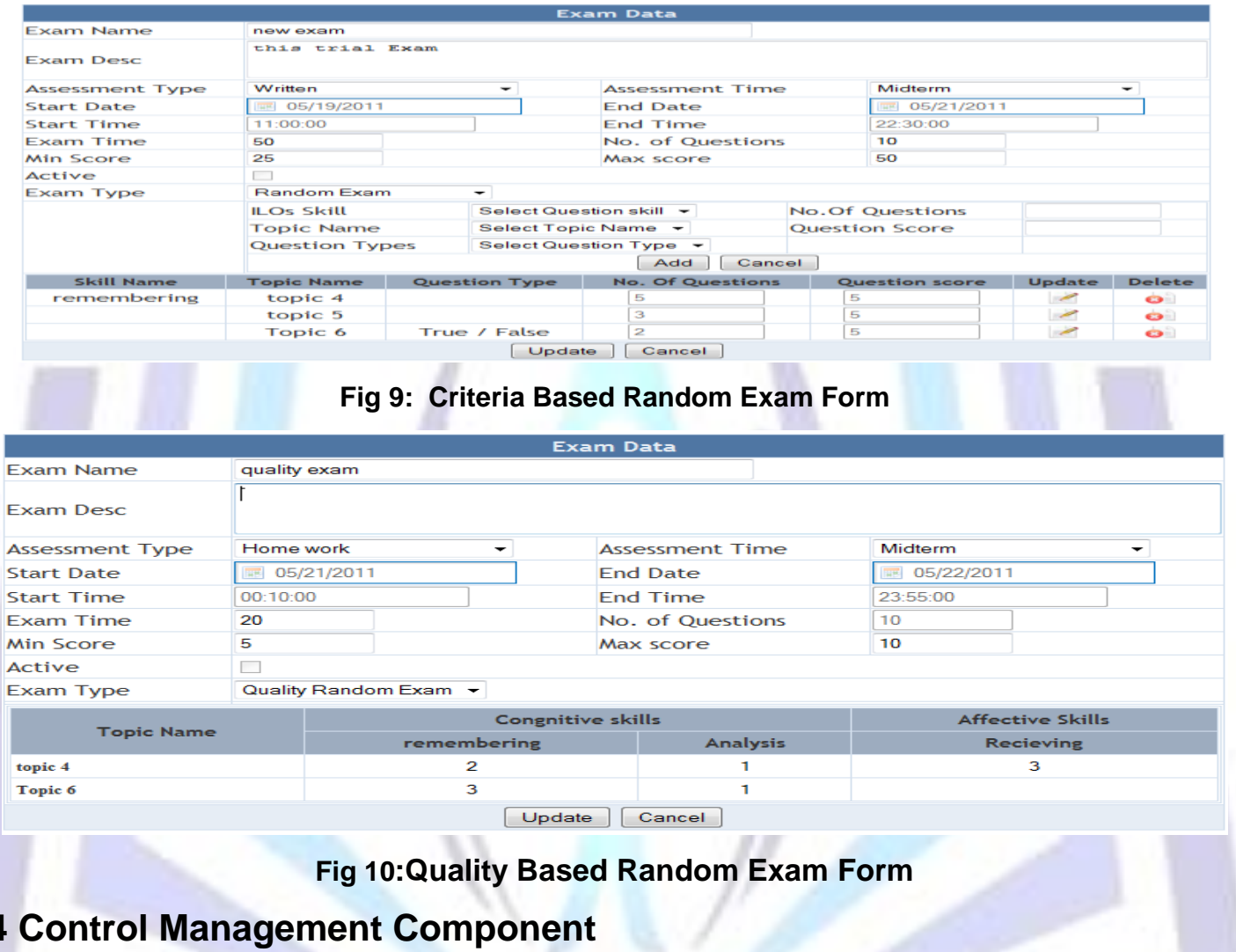

This component automates the control processes such as activating examination, determine examined students, send essay questions to faculty to correct them, show exams' results, and manage special cases such as illness cases...etc. Figure 11 shows the forms which used to manage Control processes.

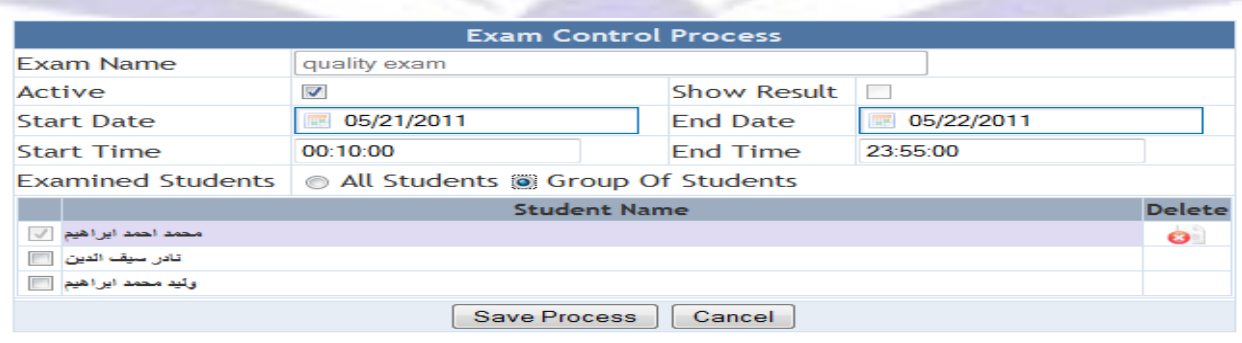

Fig 11: Exam Control Form

\subsection{Exam Engine component}

This component manages all types of examination process such as random exams, quality based exams, written exams, oral exams, practical exams, homework exams...etc. Figures 12 and 13 show the forms which used to manage Examination process. 


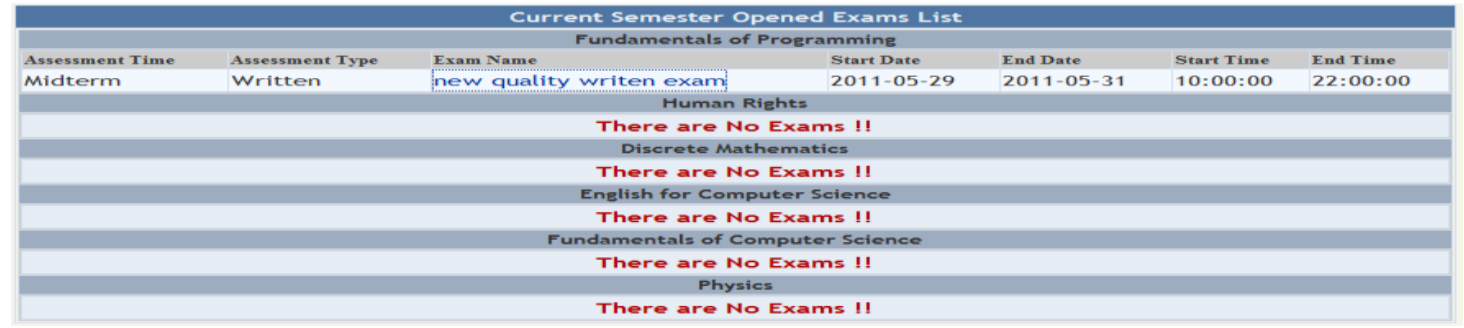

Fig 12: Current Semester courses and available Exams list

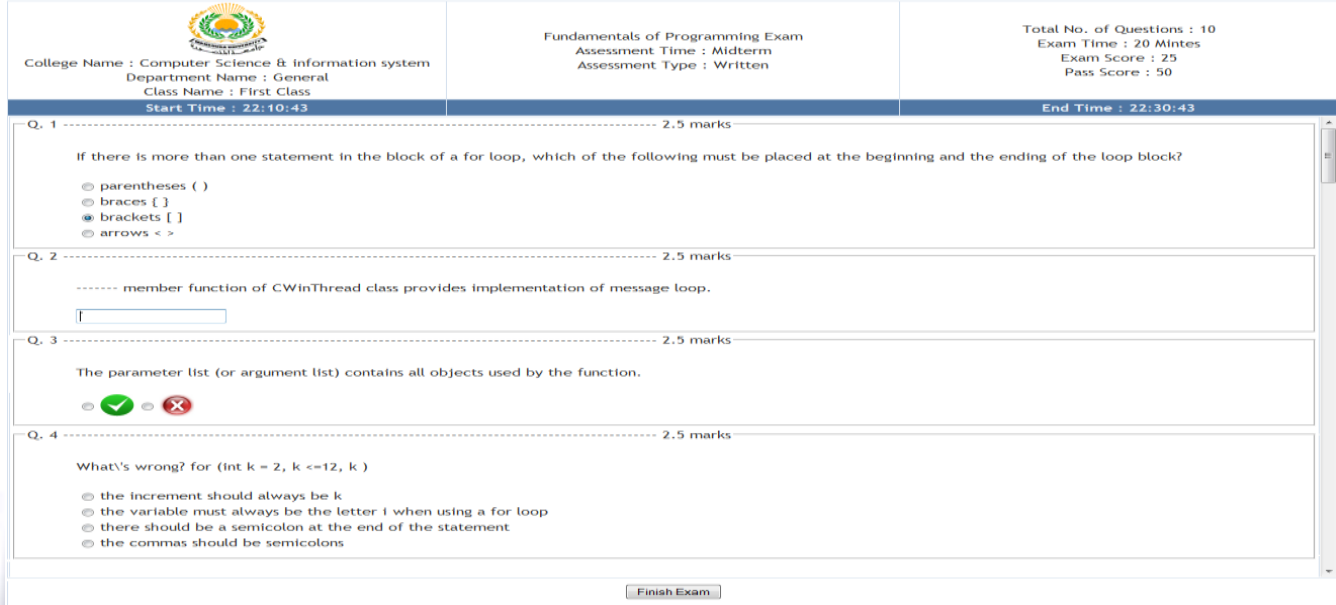

Fig 13: Examination Form

\subsection{Evaluation Component}

This is the most important component of the SAPMS. This component used to evaluate students' examination data and provide information and statistics which demonstrates the progress in students' performance and strength and weak points in students' performance. Figure 14 and 15 show the sample of statistical and graphical representation of assessment reports provided by th SAPMS.

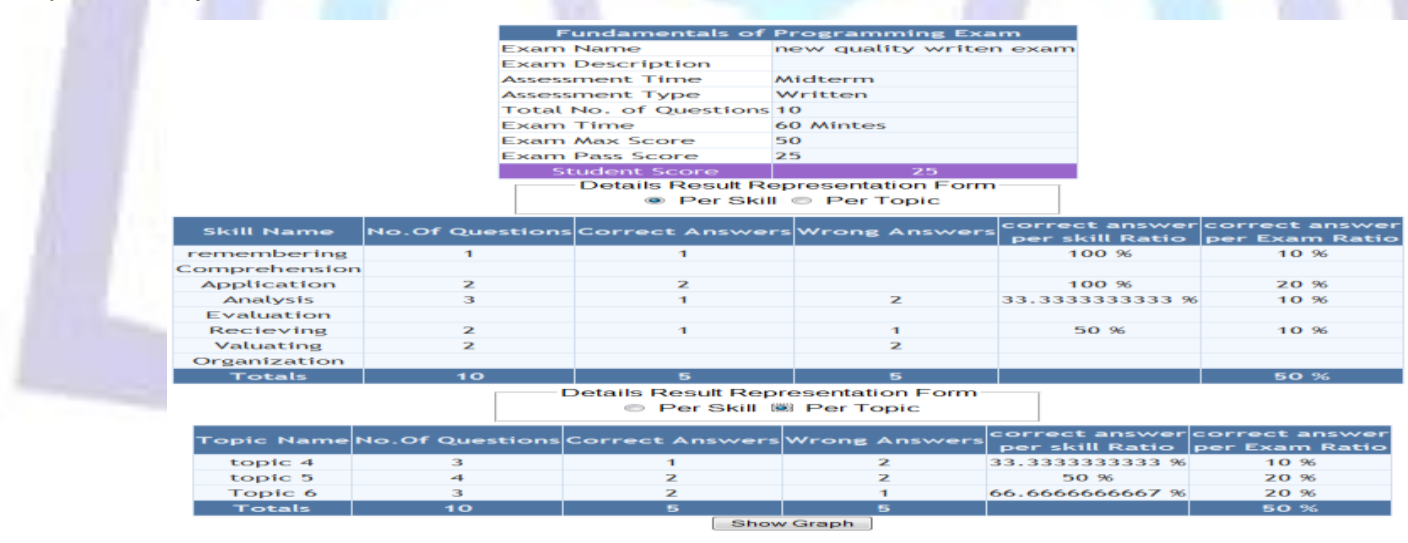

Fig 14: Evaluate Student Exam Per Skill \&Per Topic Statistical Form

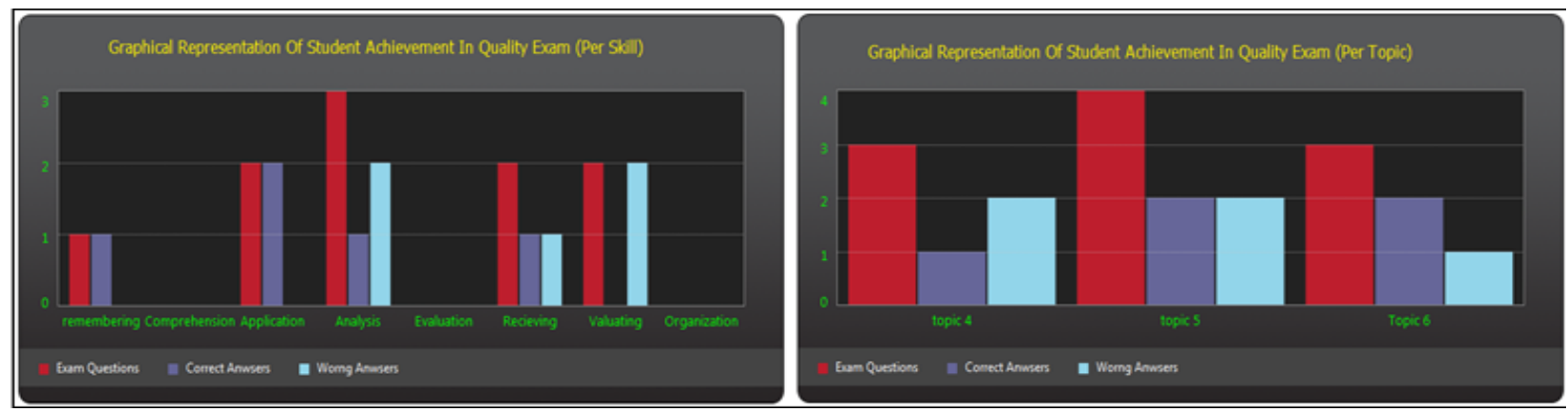

Fig 15: Evaluate Student Exam Per Skill \&Per Topic Graphical Form 


\section{SAPMS VALIDATION}

In the following section, we will illustrate the validation study that had been performed in this thesis.

\subsection{Study Objective}

Measure the effect of using SAPMS on detecting the performance's strength and weakness of both instructor and students and improve their performance in teaching and learning.

\subsection{Study Sample}

- 100 students in 1st year in Electrical Engineer Department (EED) - Faculty of Engineering - Mansoura University.

- 100 students in 2nd year in EED- Faculty of Engineering - Mansoura University.

- Study had been performed using 2 courses of Electrical Engineer Program of 1st and 2nd year. These courses were taught by one instructor "Dr. Ahmed Elsayed Hassan".

\subsection{Study Procedures}

- Data of courses had been entered (ILOs, Course Description, Topics, and Exam Quality Matrix).

- The question bank of the 2 courses had been built by saving 50 questions of different types, skills, and topics for each course.

- Students' data had been recorded and accounts data sent to each one of them.

- One Quality Based Exam was built for each course. Each exam composed of 10 questions which are randomly selected. Each exam's time was 30 minutes.

- "First Time Exam" had been made for all students in each course.

- Display results for each student and expose his strength and weakness points in his performance to improve his performance.

- $\quad$ Display these results to instructor as follow:

1. Overall students result is displayed exposing the strength and weakness points in their overall performance to guide instructor to improve his teaching methods and concentrate on shortage points.

2. Show results for each individual student which can be used by instructor as recommendation feedback to students.

- Another Quality Based Exam "Last Time Exam" with the same characteristics of the first time exam.

- Compare the results of the "First Time Exam" and "Last Time Exam" and display the comparison results for each student and for all students.

\subsection{Study Results:}

\section{- For Overall Students}

\section{Fundamental of Programming Course of $1^{\text {st }}$ Year of EED:}

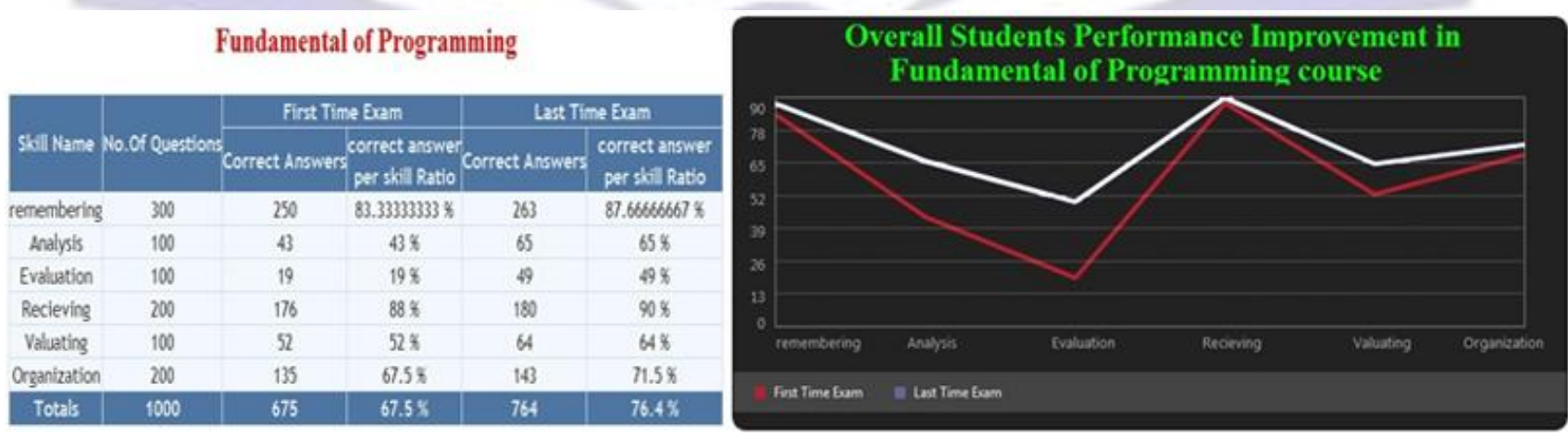

Fig 16: Students Performance improvement in Fundamental of Programming Course 


\section{Matlab Course of 2nd Year of EED:}

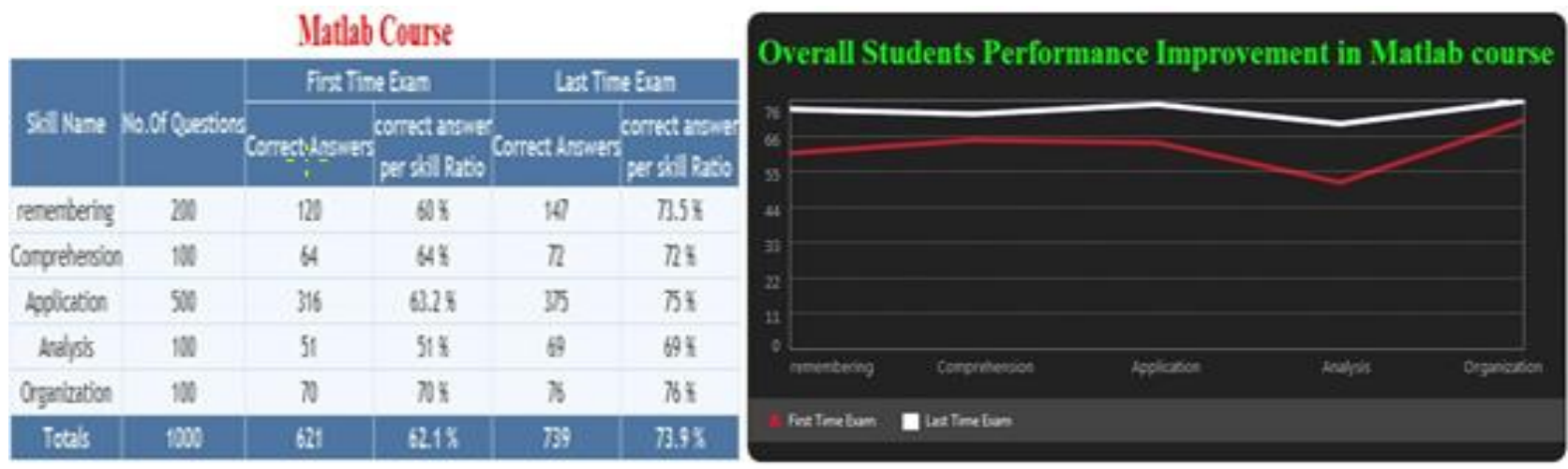

Fig 17: Students Performance improvement in Matlab Course

3. 2 Courses:

\begin{tabular}{|c|c|c|c|c|c|}
\hline \multirow[b]{2}{*}{ Skal Name } & \multirow[b]{2}{*}{ No. of Questional } & \multicolumn{2}{|c|}{ First Time Eam } & \multicolumn{2}{|c|}{ Last Time Exam } \\
\hline & & Correst Anawers & $\begin{array}{l}\text { correct answers } \\
\text { per akill Rabio }\end{array}$ & Correct Answars & $\begin{array}{l}\text { correct answe: } \\
\text { per skat Ratio }\end{array}$ \\
\hline remembering & 500 & 370 & 74 & 410 & 82 \\
\hline Compretension & 100 & SA & 64 & $n$ & $n$ \\
\hline Application & 500 & 316 & 63.2 & 375 & 75 \\
\hline Analysis & 200 & 94 & 4 & 134 & 67 \\
\hline Evaluetion & 100 & 19 & 19 & 49 & 49 \\
\hline Recieving & 200 & 176 & $8 s$ & 180 & 90 \\
\hline Valuating & 100 & 52 & 52 & 64 & 64 \\
\hline Organlzation & 300 & 205 & 68.33333333 & 219 & 73 \\
\hline Toxals & 2000 & 1298 & 64.8 & 1503 & 75.15 \\
\hline
\end{tabular}

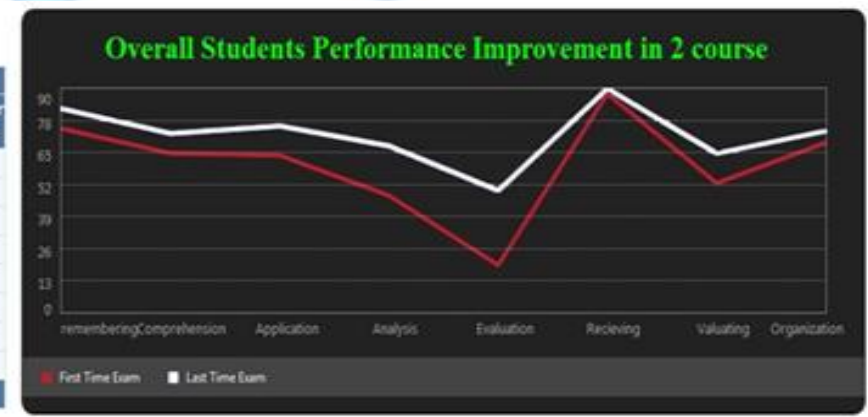

Fig 18: Overall Students Performance improvement in 2 Courses

\section{- For Individual Student}

\section{One Student of $1^{\text {st }}$ year of EED:}

Fundamental of Programming
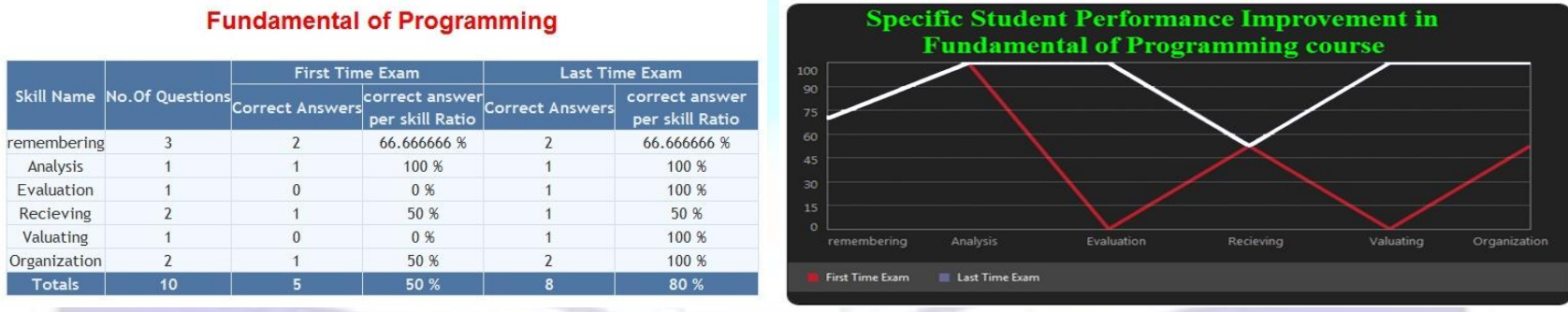

Fig 19: Individual Student Performance improvement in Fundamental of Programming Course

One Student of $1^{\text {st }}$ year of EED:

\begin{tabular}{|c|c|c|c|c|c|}
\hline \multirow[b]{2}{*}{ Skill Name } & \multirow[b]{2}{*}{ No. Of Questions } & \multicolumn{2}{|c|}{ First Time Exam } & \multicolumn{2}{|c|}{ Last Time Exam } \\
\hline & & Correc & $\begin{array}{l}\text { correct answer } \\
\text { per skill Ratio }\end{array}$ & Correct Answers & $\begin{array}{l}\text { correct answer } \\
\text { per skill Ratio }\end{array}$ \\
\hline remembering & 2 & 1 & $50 \%$ & 1 & 508 \\
\hline Comprehersion & 1 & 0 & $0 \%$ & 0 & $0 \%$ \\
\hline Application & 5 & 3 & $60 \%$ & 4 & 808 \\
\hline Analysis & 1 & 0 & $0 \%$ & 1 & $100 \%$ \\
\hline Organization & 1 & 1 & $100 \%$ & 1 & $100 \%$ \\
\hline Totals & 10 & 5 & $62.1 \%$ & 7 & $70 \%$ \\
\hline
\end{tabular}

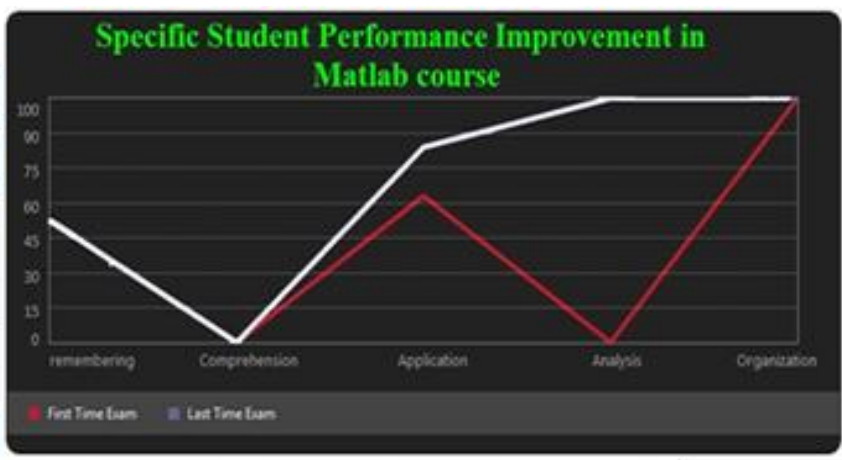

Fig 20: Individual Student Performance improvement in Matlab Course 
Based on those results, a validation study is presented to measure the effect of using SAPMS in detecting Students' and instructors' performance strength and weakness points and curves which show the student and instructor performance impacts are displayed.

\section{Conclusions}

We provide new student assessment system based on quality perspectives which aides all stockholders in educational environment in improving their performance to reach better results. Our system is called SAPMS. The analysis and design of the proposed system were presented briefly. After that we showed set of screen shots of that represent the developed system. Finally, we illustrated the validation process which performed on students of two classes in two subjects for each class. This validation showed the student strength and weakness points in their skills and for each topic which help both students and teachers of them from improving the student's skills.

\section{REFERENCES}

[1] P. Black and D. Wiliam, "Inside the black box: Raising standards through classroom assessment", Phi Delta Kappan, vol. 80, no. 2, pp. 139-148,1998.

[2] XiaoMing Cao, Xiangrui Wang ; "A Computer- Assisted Assessment and Diagnosis System for Arts Students-Oriented Computer Education", proceeding of IEEE International Conference on Education Technology and Computer;pages 289-293; IEEE DOI 10.1109/ICETC.2009.53;2009.

[3] Alexandru Botu, Adrian Badoiu,Sanda Petrescu, and Vasilica Vlad; " SIIPAL A Public Administration e-Learning System. Student Assessment.", proceeding of IEEE International Conference on Automation, Quality and Testing, Robotics ;pages 167 - 170 ; 1-4244-0360-X ; 2006.

[4] Eugene Essa, Andrew Dittrich, Sergiu Dascalu, Frederick C. Harris, Jr. , "ACAT: A Web-based Software Tool to Facilitate Course Assessment for ABET Accreditation" , proceeding of IEEE Seventh International Conference on Information Technology;pages 88-93; 978-0-7695-3984-3/10; 2010.

[5] Fahad T. Alotaiby, Jim X. Chen, Harry Wechsler, Edward J. Wegman,and Debra Sprague," Adaptive Web-based Learning System", Proceedings of the 12th IEEE International Conference and Workshops on the Engineering of Computer-Based Systems (ECBS'05), 0-7695-2308-0/05, 2005.

[6] Andrea Gorra, Andrea Gorra, and Jackie Campbell," An Account of the Use of Integrated Assessment for Students in the Area of Databases at Level 2", Proceedings of the 24th British National Conference on Databases (BNCOD'07) ; 0-7695-2912-7/07, 2007.

[7] Judit Jassó, Alfredo Milani, and Simonetta Pallottelli," Blended e-learning: survey of on-line student assessment", Proceedings of the IEEE 19th International Conference on Database and

[8] Fahad T. Alotaiby, Jim X. Chen," Generic Summative Assessment Functional Model", Proceedings of the Sixth IEEE International Conference on Software Engineering, Artificial Intelligence, Networking and Parallel/Distributed Computing and First ACIS International Workshop on Self-Assembling Wireless Networks (SNPD/SAWN'05) 0-76952294-7/05, 2005.

[9] Ni Hao; Liu Fanghua, "Quantitative Assessment of Students' Learning Activity Based on Students' Electronic Portfolio of Web-based Instruction System" ,The 1st International Conference on Information Science and Engineering; (ICISE2009); 978-0-7695-3887-7/09, IEEE Computer Society,2009.

[10] loannis Hatzily geroudis, Constantinos Koutsojannis, Constantinos Papavlasopoulos , Jim Prentzas ;"KnowledgeBased Adaptive Assessment in a Web-Based Intelligent Educational System";Proceedings of the Sixth International Conference on Advanced Learning Technologies; (ICALT'06); 0-7695-2632-2/ IEEE Computer Society,2006.

[11] http://www.cognero.com/features.html Last access November 20, 2010.

[12] Full Circle Assessment, Available: http://www.cognero.com/features.html, Last access November 20, 2010.

[13] Assessment Delivery Engine, Available: http://www.asdel.ecs.soton.ac.uk/, Last access November 21, 2010.

[14] G. Wills, J. Hare, J. Kajaba, , D. Argles, L. Gilbert, D. and Millard, "Assessment Delivery Engine for QTIv2 Tests", In: International CAA Conference, 8-9th July 2008, Loughborough UK.,2008.

[15] Assessment Tools for Learning Systems, Available: http://www.respondus.com/products/respondus.shtml, Last access November 21, 2010.

[16] Articulate Network, Available : http://www.articulate.com/support/help/quizmaker/v2/, Last access November 21, 2010.

[17] TCExam, Free Computer-Based Assessment Software, Available: http://www.tcexam.org/\#community.\%E2\%80\%8E , Last accessed May 21, 2011. 